\title{
PENDEKATAN KEILMUAN TERHADAP FENOMENA KEAGAMAAN
}

\section{SCIENCE APPROACH TO RELIGIOUS PHENOMENON}

\author{
Erwin Jusuf Thaib ${ }^{1}$ \\ ${ }^{1}$ IAIN Sultan Amai Gorontalo erwinjthaib@iaingorontalo.ac.id.
}

\begin{abstract}
In general, the teachings of Islam which are written in the Qur'an and the Hadith only recognize two forms related to their form of determination, the first is in the form of qath' $i$ as a doctrine that has a definite meaning, remains in its implementation and does not change. This is usually related to matters relating to religious principles and worship. The second form which is zhanni is a doctrine that is dynamic both in meaning and form of its implementation. This is mainly related to muamalah problems. Related to the two things above, the approach to various religious phenomena is polarized towards the two things. Religious phenomena that are qath'i use the ta'abbudi approach which in principle uses more submission in the name of faith in the omnipotence of God Almighty. As for the religious phenomena that are zhanni, the approach used is ta'aqquli which emphasizes the power of logic and rationality of human reason.
\end{abstract}

Keywords: qath'i, zhanni, ta'abbudi, ta'aqquli

\begin{abstract}
Abstrak: Secara umum ajaran agama Islam yang tersurat dalam Al-Qur'an dan Hadis hanya mengenal dua bentuk terkait dengan bentuk ketetapannya yakni yang pertama berbentuk qath'i sebagai doktrin yang bersifat pasti maknanya, tetap dalam pelaksanaannya dan tidak berubah-ubah. Hal ini biasanya berkaitan dengan masalah-masalah yang berkaitan dengan prinsip-prinsip agama dan ibadah. Adapun bentuk yang kedua yang bersifat zhanni yaitu sebuah doktrin yang bersifat dinamis baik dalam makna dan bentuk pelaksanaannya. Hal ini terutama yang berhubungan dengan masalah muamalah. Terkait dengan kedua hal di atas, maka pendekatan terhadap berbagai fenomena keagamaan terpolarisasi terhadap kedua hal tersebut. Fenomena keagamaan yang bersifat qath'i menggunakan pendekatan ta'abbudi yang secara prinsip lebih menggunakan sikap ketundukan atas nama iman atas kemahakuasaan Allah swt. Adapun fenomena keagamaan yang bersifat zhanni maka pendekatan yang digunakan adalah ta'aqquli yang mengedepankan kekuatan logika dan rasionalitas akal manusia.
\end{abstract}

Kata Kunci : qath'i, zhanni, ta'abbudi, ta'aqquli 
Jurnal Pemikiran Konstruktif Bidang Filsafat dan Dakwah

ISSN $1907-0993$

E ISSN $2442-8264$

Vol. 17 No. 1, Juni 2020

\section{A. PENDAhuluan}

Perdebatan tentang posisi akal dan wahyu dalam menginterpretasi ajaran agama Islam dapat digambarkan sebagai sebuah perdebatan yang sengit di antara para pemikir dan filosof Islam. Pada umumnya perdebatan ini diwarnai dengan argumentasi yang beragam tentang sejauh mana akal bisa menginterpretasi agama dan sampai dimana batasan yang informasinya hanya bisa dijelaskan melalui wahyu. Sejatinya penggunaan akal untuk menginterpretasi agama bukan sesuatu yang dilarang dalam Islam. Agama Islam sangat menjunjung tinggi kedudukan akal. Dengan akal, manusia dapat memahami Al-Qur'an sebagai wahyu yang diturunkan lewat Nabi Muhammad saw, dengan akal juga manusia mampu menelaah Kembali sejarah Islam dari masa ke masa hingga sampai kepada saat ini. ${ }^{1}$

Pada umumnya banyak ilmuwan Islam berpandangan bahwa interpretasi wahyu dengan wahyu akan cenderung lebih obyektif, sebaliknya interpretasi wahyu dengan akal akan cenderung subyektif. Dengan demikian pengetahuan yang diperoleh melalui penafsiran wahyu atas wahyu dianggap memiliki kebenaran yang absolut. Dan sebaliknya pengetahuan yang bersumber dari interpretasi akal atas wahyu bersifat nisbi. ${ }^{2}$ Meskipun demikian, beberapa pemikir Islam seperti Nurcholish Madjid berpandangan bahwa akal dan wahyu sebagai sumber kebenaran dan keduanya bersumber dari sumber yang sama yakni Allah swt, maka menjadi suatu keniscayaan kalua hasil pencapaian antara wahyu dan akal bermuara pada kebenaran yang sama. ${ }^{3}$

Polemic panjang tentang posisi akal dan wahyu dalam peranannya menginterpretasi agama senantiasa mewarnai ranah pemikiran Islam sejak era

\footnotetext{
${ }^{1}$ Efrianto Hutasuhut, Akal dan Wahyu dalam Islam (Perbandingan Pemikiran Harun Nasution dan Muhammad Abduh) dalam Jurnal Al-Lubb Volume 2 Nomor 1 Tahun 2017, h. 177

${ }^{2}$ Masbukin dan Alimuddin Hasan, Akal dan Wahyu, Antara Perdebatan dan Pembelaan dalam Sejarah, dalam Jurnal Toleransi: Media Komunikasi Umat Beragama Volume 8 Nomor 2 Tahun 2016 h. 153

${ }^{3}$ Masbukin dan Alimuddin Hasan, Akal dan Wahyu, h.154
} 
Jurnal Pemikiran Konstruktif Bidang Filsafat dan Dakwah

ISSN $1907-0993$

E ISSN $2442-8264$

Vol. 17 No. 1, Juni 2020

tabi'in hingga hari ini. Polemik inilah yang dipandang sebagai sumber lahirnya beragam aliran dalam sejarah pemikiran manusia ${ }^{4}$ termasuk diantaranya aliran keagamaan dalam Islam. Dalam Islam dikenal begitu banyak aliran keagamaan yang dipengaruhi pemikiran tentang aqidah, kalam, tauhid, tasawuf, politik, dan lain sebagainya. Semua permasalahan tiak bisa dilepaskan dari polemik tentang akal dan wahyu.

Wahyu dan akal sejatinya merupakan dua entitas yang tidak perlu dipertentangkan secara diametral. Wahyu sebagai tuntunan Ilahi diturunkan tidak lain bermaksud membimbing entitas akal menuju jalan yang benar sesuai dengan rambu-rambu Tuhan. Sebaliknya akal pikiran diciptakan untuk menjadi tolok ukur dalam menentukan baik buruk, suci-najis, maslahat-mafsadah. ${ }^{5}$ Semua polemik ini pada dasarnya didasari oleh niat yang mulia untuk semakin memahami maksud dan tujuan yang dikandung oleh ajaran Islam.

Ajaran Islam yang dibawa oleh Nabi Muhammad SAW sebagai tuntunan umat manusia guna mencapai kesejahteraan dunia dan akhirat. Pokok ajarannya termuat dalam Al-Qur'an dan Al-Sunnah sebagai pedoman, karena keduanya mengandung aturan-aturan, hukum-hukum, dan ajaran peribadatan, baik yang mengatur manusia dalam hubungannya dengan manusia lainnya, maupun dalam hubungannya dengan Allah SWT.

Secara normatif, ajaran Islam disebut sebagai rahmat bagi seluruh alam semesta karena dibawa oleh seseorang yang oleh Allah SWT dinyatakan sebagai rahmatan lil'alamin. Ini berarti bahwa ajaran-ajaran Islam pastilah bersifat aplikatif dan dapat diwujudkan secara nyata dalam keseharian. Setiap ajaran Islam mestilah layak diterima oleh semua lapisan masyarakat. Bahkan, ajaran ini mestilah sesuai dengan semua perubahan dan perkembangan yang dicapai oleh dinamika sosial masyarakat Islam itu sendiri.

\footnotetext{
${ }^{4}$ Sabara, Polemik Akal dan Wahyu dalam Lanskap Pemikiran (Antara Rasionalisme vis a vis Fideisme) dalam Jurnal Ilmu Aqidah Volume 1 Nomor 1 Tahun 2015, h.100

${ }^{5}$ Diki Candra, Akal dan Wahyu : Telaah Atas Pemikiran Kalam Harun Nasution dalam Jurnal Ad-Dirasah, Jurnal Hasil Pembelajaran Ilmu-ilmu Keislaman Volume 1 Nomor 1, 2018, h. 82
} 
Jurnal Pemikiran Konstruktif Bidang Filsafat dan Dakwah

ISSN $1907-0993$

E ISSN $2442-8264$

Vol. 17 No. 1, Juni 2020

Adanya wahyu yang diturunkan oleh Allah SWT sebagai sumber ajaran Islam dapat diterima manusia dengan keyakinan, meski kemampuan akal dalam memahami wahyu itu belum dapat menjangkau secara keseluruhan, utamanya yang berkaitan dengan masalah muamalat ${ }^{6}$ dan hubungan antar manusia dapat dideteksi dengan pendekatan rasional. Dalam kaitannya dengan masalah ibadah, tidak berarti bahwa dengan adanya wahyu maka akal tidak berfungsi lagi. Namun hal tersebut harus digunakan oleh manusia secara bersama untuk memperoleh kebajikan.

Dalam masalah ibadah yang bersifat qath'i tidak berlaku dalil qiyas atasnya. Karena qiyas yang diasarkan pada pengetahuan terhadap illat (alasan dasar / ratio legis) hukum, sedagkan hukum-hukum yang bersifat qath'i tidak dapat diketahui dengan jalan demikian seperti shalat, akal tidak dapat menarik illat atasnya. Sebaliknya dalam bidang muamalat dapat berlaku hukum qiyas karena dapat mengetahui illat yang menyebabkan lahirnya hukum syara' seperti keharaman khamar dan judi, juga keharaman menahan harta orang. ${ }^{7}$

Kedua hal di atas - ibadah dan muamalah - adalah fenomena keagamaan yang realitasnya bisa ditemukan dalam keseharian orang Islam. Dari uraian ringkas di atas, sudah dapat dipahami bahwa fenomena-fenomena keagamaan itu pada dasarnya bisa didekati dengan berbagai pendekatan yang salah satunya dengan pendekatan keilmuan yang memberi peran cukup besar bagi akal pikiran manusia untuk terlibat perumusan berbagai hal yang terkait dengannya.

Ta'aqquli dan Ta'abbudi dalam karakteristik hukum Islam adalah hukum Islam mengandung muatan dimensi vertikal dan horizontal. Hukum Islam

\footnotetext{
${ }^{6}$ Fiqih muamalah mengatur masalah kebendaan dan hak-hak atas benda, aturan mengenai jual beli, sewa menyewa, pnjam meminjam, persyarikatan (kerja sama bagi hasil), pengalihan hak, dan segala yang berkaitan dengan transaksi. (Lihat, Aisyah Arsyad, Memahami Rahasia Hukum Dalam Ruang Privat ( Huquq Al-Ibad), dalam Jurnal Sulesana Volume 11 Nomor 2 Tahun 2017) h.18

${ }^{7}$ Abu Zahrah, Ushul Al-Fiqh (Kairo; Dar Al-Fikr Al-Arabi, t.th.) h. 173. Lihat juga Bidran Abu Ainain Bidran, Al-Ibadat Al-Islamiyah (Iskandariyah; Mu'assasah Syabaab Al-Jami'ah, 1973) h. 3.
} 
Jurnal Pemikiran Konstruktif Bidang Filsafat dan Dakwah

ISSN $1907-0993$

E ISSN $2442-8264$

Vol. 17 No. 1, Juni 2020

bersumber kepada wahyu yang mengandung muatan teologis menunjukan aturan tentang hubungan antara manusia dengan Tuhan yang diyakini sebagai pembuat hukum secara mutlak. Konsekuensinya ada keharusan bagi orang Islam untuk tunduk dan patuh terhadap hukum Islam. Namun demikian, tidak semua hukum Islam itu kaidah norma hukumnya berbentuk khusus dan jelas, malainkan diperlukan suatu bentuk penafsiran atas segi-segi hukum yang umum. Pada tingkatan metodologi, interpretasi atas segi norma hukum dalam nash kemudian dikonkretkan menjadi produk hukum (fiqh) yang lebih menyentuh sisi praktis pelaksanaan hukum Islam. ${ }^{8}$

Pertanyaan terbesar yang harus dijawab dalam tulisan ini adalah seberapa jauh akal sebagai sarana analisa keilmuan dapat memasuki, mencampuri dan bahkan memberi pertimbangan-pertimbangan bagi ketetapan hukum atas fenomena-fenomena keagamaan tersebut. Hal inilah yang menjadi pokok permasalahan dari tulisan ini yang selanjutnya akan dikembangkan pada bagian pembahasan tulisan ini.

\section{B. PENDEKATAN ATAS FENOMENA KEAGAMAAN : TA'ABBUDI DAN TA'AQQULI}

Ajaran agama Islam sebagaimana yang termaktub dalam dua sumber utama yakni Al-Qur'an dan Hadis senantiasa memberi ruang untuk terjadinya proses interpretasi terhadap ajaran yang dikandungnya. Itulah sebabnya sepanjang sejarah Islam ini ada, maka penafsiran terhadap Al-Qur'an dan Hadis terus berlangsung sejak zaman Nabi Muhammad saw hingga hari ini. Kepustakaan dunia Islam mengenal ribuan kitab tafsir dan syarah hadis dengan berbagai corak penafsiran baik yang bersifat klasik maupun kontemporer.

Pada dasarnya syariat Islam, baik yang bersumber dari Al-Qur'an maupun hadis ada yang bersifat tetap (tsabit), tidak boleh berubah, dan ada pula yang bisa

${ }^{8}$ Didi Kusnadi, Pemikiran Hukum Islam Klasik dan Modern: Karakteristik, Metode, Pengembangan, dan Keberlakuannya, dalam Jurnal Asy-Syar'iyah Volume 16 Nomor 1 Tahun 2014, h. 3-4 
Jurnal Pemikiran Konstruktif Bidang Filsafat dan Dakwah

ISSN $1907-0993$

E ISSN $2442-8264$

Vol. 17 No. 1, Juni 2020

berubah dan boleh diubah. Bahkan ajaran Islam yang disebut terakhir jumlahnya justru lebih banyak daripada yang pertama. ${ }^{9}$

Terbukanya ruang interpretasi atas ajaran Islam memperlihatkan bahwa Islam bisa mentoleransi pemikiran keagamaan sejauh tidak melenceng dari prinsip utama ajaran Islam. Karena dalam kedua sumber ajaran di atas, terdapat ayat atau hadis yang pemahamannya bisa didekati dengan kemampuan rasional manusia, namun ada aspek yang harus diterima dengan pendekatan keimanan. Kedua pendekatan ini dikenal dengan istilah ta'abbudi dan ta'aqquli yang akan dijelaskan berikut ini.

\section{Ta'abbudi}

Secara etimologis kata ta'abbudi berasal dari Bahasa Arab, sebagai masdar dari fi'il ta'abbada, yata'abbadu, ta'abbudan yang menurut Ibnu Manzhur berarti penghambaan diri, ketundukan, dan kerendahan diri. ${ }^{10}$ Istilah ta'abbudi diartikan sebagai "ghairu ma'qulatil ma'na" (harus diikuti apa adanya / taken for granted) adalah konsep yang didalamnya mengandung ajaran Islam yang baku yakni ajaran yang berkaitan dengan tauhid. ${ }^{11}$ Ta'abbudi bersifat permanen, statis dan tidak mengalami perubahan. Prinsip ta'abbudi tidak mengenal keragaman dalam pelaksanaannya ${ }^{12}$ Dari definisi ini terlihat bahwa aspek-aspek yang harus didekati dengan pendekatan ta'abbudi dalam ajaran Islam adalah aspek-aspek pokok atau inti seperti ajaran tentang tauhid. Ajaran tentang tauhid berkaitan dengan ajaran ketuhanan yang merupakan intisari dari

\footnotetext{
${ }^{9}$ M. Fatih, Paradigma Pemahaman dan Klasifikasi Sunnah dalam Perspektif Edukatif Mahmud Syaltut dan Implikasinya Terhadap Aktualisasi Mekanisme Ra'yu Era Kekinian, dalam Ta'dibia Jurnal Ilmiah Pendidikan Islam Volume 7 Nomor 1, 2017, h. 15

${ }^{10}$ La Jamaa, Konsep Ta'abbudi dan Ta'aqquli dan Implikasinya Terhadap Perkembangan Hukum Islam, dalam ASy-Syir'ah, Jurnal Ilmu Syari'ah dan Hukum, Volume 47 No.1 Tahun 2013, h. 4

${ }^{11}$ Abdul Qodir Zaelani, Konsep Ta'aqquli dan Ta'abbudi dalam Konteks Hukum Keluarga Islam, dalam Jurnal ASAS Volume 6 Nomor 1, 2014, h. 47

${ }^{12}$ Fitriyani, Hukum Islam dan Multikulturalisme di Indonesia, dalam Jurnal Tahkim Volume 12 Nomor 2 Tahun 2018, h. 8
} 
Jurnal Pemikiran Konstruktif Bidang Filsafat dan Dakwah

ISSN $1907-0993$

E ISSN $2442-8264$

Vol. 17 No. 1, Juni 2020

ajaran Islam. Tauhid menjadi landasan normatif bagi aspek ajaran Islam lainnya seperti ibadah, akhlak dan muamalah.

Aspek-aspek ketauhidan dalam ajaran Islam adalah aspek yang sepenuhnya harus diterima secara ta'abbudi. Tauhid yang menekankan doktrin tentang ke-Esa-an Allah swt, tidak dapat diperdebatkan lagi kebenarannya. Umat Islam harus menerima secara mutlak doktrin ini sebagai pintu masuk keberimanan dan keber-Islaman. Seorang Muslim tidak akan pernah terhindar dari penerimaan akan doktrin tentang Allah swt sebagai ahad atau satu dan tidak ada yang menyamainya. Inilah realitas paling mendasar dari konsep pendekatan ta'abbudi dalam ajaran Islam.

Pada dasarnya manusia diciptakan oleh Allah SWT agar senantiasa mengabdi dan taat kepada-Nya untuk kebahagiaan dan kemaslahatan manusia itu sendiri. Hal tersebut dinyatakan oleh Allah SWT dalam surat Al-Dzariyaat ayat 56:

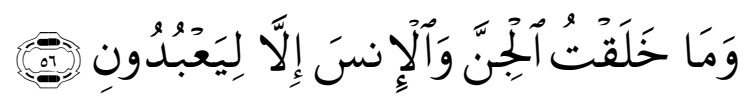

Dalam ayat di atas, Allah SWT menjelaskan bahwa hakekat penciptaan manusia adalah untuk beribadah atau menyembah kepada-Nya. Ibadah dalam Islam sebenarnya bukan bertujuan agar supaya Tuhan disembah dalam pengertian yang menyerupai penyembahan terdapat dalam agama-agama primitif, karena Tuhan tidak berhak berhajat untuk disembah atau dipuji oleh manusia. Oleh karena itu kata "liya'budu" dalam ayat ini berarti patuh dan tunduk. $^{13}$

Dalam kaitannya dengan upaya memahami dan menerima perintah Tuhan sebagai suatu fenomena keagamaan maka sikap tunduk dan patuh terhadap segala perintah Tuhan adalah suatu sikap yang populer dengan sebutan Ta'abbudi dalam pengertian bahwa sikap tunduk dan patuh terhadap perintah

\footnotetext{
${ }^{13}$ Harun Nasution, Islam Ditinjau Dari Berbagai Aspeknya, (Jakarta; UI Press, 1985) h. 38.
} 
Jurnal Pemikiran Konstruktif Bidang Filsafat dan Dakwah

ISSN $1907-0993$

E ISSN $2442-8264$

Vol. 17 No. 1, Juni 2020

tersebut adalah dalam rangka penyembahan kepada Allah SWT, tanpa adanya sikap menolak atau membantah perintah tersebut.

Dalam hubungannya dengan masalah ibadah, As-Syathibi menjelaskan bahwa penyembahan kepada Allah SWT dapat disebabkan oleh dua hal yaitu:

a. Ibadah yang fungsi utamanya mendekatkan diri kepada Allah SWT yaitu beriman kepada-Nya dengan segala konsekuensinya dalam bentuk ibadahibadah yang telah disyariatkan yang bersifat ukhrawi dan merupakan hak Allah SWT untuk ditaati dan diikuti.

b. Perilaku adat yang terjadi di kalangan hamba yang bertujuan mewujudkan kemaslahatan secara mutlak. Hal ini disyari'atkan guna meraih kemaslahatan hamba dan mencegah kerusakan bagi mereka. Hal ini bersifat duniawi dan dapat dipahami akal manusia. ${ }^{14}$

Bila diperhatikan pembagian di atas maka bahagian yang pertama adalah porsi ta'abbudi karena masalah-masalah yang menyangkut ibadah murni, maka yang terkandung didalamnya tidak dapat dipahami oleh akal karena merupakan hak mutlak Allah SWT. Adapun bagian yang kedua adalah porsi ta'aqquli yang banyak melibatkan pemikiran manusia di dalamnya.

Oleh karena itu, dalam masalah ibadah, hamba harus menerima ketetapan syariat tanpa menambah atau mengurangi karena dalam hal ibadah berlaku ketentuan kaidah ushul :

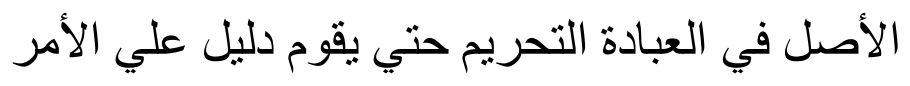

Artinya: "Dasar dari sebuah ibadah (penyembahan) adalah haram sampai ada dalil yang memberitahukannya." 15

Dengan demikian dalam masalah ibadah, seseorang hanya dibolehkan melakukan apabila ada nash yang memberitahukan, karena dalam bidang ini tidak berlaku ijtihad dan penalaran. Akal manusia sebagai alat analisa keilmuan

\footnotetext{
${ }^{14}$ Abu Ishak As-Syathibi, Al-Muwafaqaat (Beirut; Dar Al-Ma'rifat, t.th) h. 215

${ }^{15}$ Hamka Haq, Filsafat Ilmu Fiqhi (Ujung Pandang; Yayasan Al-Ahkam, 1999) h. 161
} 
Jurnal Pemikiran Konstruktif Bidang Filsafat dan Dakwah ISSN $1907-0993$

E ISSN $2442-8264$

Vol. 17 No. 1, Juni 2020

tidak akan bisa menjawab mengapa jumlah rakaat shalat sudah ditetapkan, mengapa berwudhu harus sesuai tertib urutannya dan masih ada berbagai pertanyaan yang tidak bisa dijawab maknanya secara pasti oleh akal, karena semua itu harus diterima dengan penuh ketundukan dan kepasrahan secara ta'abbudi.

2. Ta'aqquli

Kata ta'aqquli diartikan sebagai " ma'qulatul ma'na” (dapat dipikirkan) adalah ajaran yang perlu dikembangkan oleh akal manusia dan dirumuskan sesuai dengan perkembangan masyarakat, kebutuhan hukum, dan keadilan pada suatu masa, tempat, dan lingkungan. ${ }^{16}$ Ta'aqquli bersifat dinamis dan temporal. Ta'aqquli memberikan keleluasaan adanya keragaman sesuai pertimbangan kemaslahatan hidup manusia. Keragaman tersebut bisa jadi sesuai dengan kultul (budaya) manusia dalam setiap ruang dan waktu. ${ }^{17}$ Definisi ini memperlihatkan adanya ruang interpretasi rasional dalam ajaran-ajaran Islam khususnya untuk aspek ajaran non tauhid dan ibadah. Dalam ajaran Islam, banyak aspek-aspek social atau muamalah yang sejalan dengan dinamika masyarakat yang dalam implementasinya membutuhkan pemikiran agar bisa disesuaikan dengan perkembangan zaman dan persebaran masyarakat yang menganut ajaran Islam.

Istilah ta'aqquli dalam hukum Islam banyak terkait dengan masalah muamalah, yaitu hukum-hukum sosial yang didalamnya terdapat penalaran rasio. Artinya dalam upaya memahami dan menerimanya, umat Islam dapat menerapkan atasnya pendekatan-pendekatan keilmuan sebagai alat bantu pembenar terhadap apa yang telah ditegaskan nash.

Mengapa aspek muamalah yang menjadi fokus pada bagian ini. Hal ini disebabkan oleh kenyataan bahwa muamalah merupakan fenomena keagamaan yang mengandung pengertian yang luas yaitu mencakup segala bnetuk hubungan

\footnotetext{
${ }^{16}$ Abdul Qodir Zaelani, Konsep Ta'aqquli dan Ta'abbudi dalam Konteks Hukum Keluarga Islam, h. 48

${ }^{17}$ Fitriyani, Hukum Islam dan Multikulturalisme di Indonesia, h. 8
} 
Jurnal Pemikiran Konstruktif Bidang Filsafat dan Dakwah ISSN $1907-0993$

E ISSN $2442-8264$

Vol. 17 No. 1, Juni 2020

masyarakat dan perseorangan yang dalam istilah baru di sebut adat. Hal ini sebagaimana yang dijelaskan oleh TM Hasbi Ash-Shiddieqy yaitu: “ Adat ialah hukum-hukum yang ditetapkan untuk menyusun dan mengatur hubungan perseorangan dan masyarakat atau untuk mewujudkan kemaslahatan dunia. Hukum ini dapat dipahami maknanya dan selalu diperhatikan urf-urf dan kemaslahatan. Hal ini dapat berubah menurut perubahan makna, tempat, dan waktu serta situasi dan kondisi. Oleh karena itu hukum yang mengenai adat (muamalah) ini kebanyakan hukumnya bersifat menyeluruh, berupa kaidahkaidah yang umum yang disertai dengan illat-illat yang bisa dinalar dengan pendekatan akal. $^{18}$

Oleh karena itu, dalam upaya untuk memperoleh kemaslahatan dunia, maka agama memberi kemungkinan bagi akal untuk dapat digunakan semaksimal mungkin untuk mencari makna-makna yang terkandung dalam ketentuan Allah SWT, karena hal tersebut bersifat ta'aqquli. Dengan terbukanya peluang itu, maka kemungkinan untuk diterapkan teori-teori ilmiah seperti teoriteori ilmu sosial kemasyarakatan menjadi sangat besar. Semua itu bertujuan untuk dapatmlebih menjabarkan semua perintah Tuhan dalam konteks kekinian. Dengan demikian, klaim bahwa Islam adalah suatu sistem ajaran yang sesuai dengan segala tempat, zaman, dan waktu dapat diwujudkan dengan pendekatan pemahaman keagamaan yang bersifat ta'aqquli.

Gabungan dari kedua pendekatan, ta'abbudi dan ta'aqquli, dalam memahami fenomena keagamaan bila berlaku secara ideal akan dapat mewujudkan pemahaman Islam yang sempurna dan selanjutnya akan melahirkan Muslim yang kaaffah dan beriman kepada Islam yang kaaffah.

\section{AKAL DAN PERANANNYA DALAM MENGINTERPRETASI FENOMENA KEAGAMAAN}

\footnotetext{
${ }^{18}$ TM Hasbi Ash-Shiddieqy, Pengantar Ilmu Fiqh (Jakarta: Bulan Bintang;1974) h. 30
} 
Jurnal Pemikiran Konstruktif Bidang Filsafat dan Dakwah ISSN $1907-0993$

E ISSN $2442-8264$

Vol. 17 No. 1, Juni 2020

Akal sebagai salah satu elemen terpenting dalam kehidupan manusia mendapatkan penghargaan tertinggi dalam ungkapan ayat-ayat Al-Qur'an. Tidak sedikit ayat Al-Qur'an yang menganjurkan dan mendorong manusia supaya banyak berpikr dan menggunakan akalnya. Selain menggunakan kata-kata 'aqala untuk menunjukkan perbuatan berpikir, Al-Qur'an menggunakan terminologiterminologi sebagai berikut:

1. Nazhara, yang bermakna melihat secara abstrak dalam arti berpikir. Term ini terdapat pada lebih dari 30 ayat, di antaranya terdapat pada surat Qaf: 6-7, Al-Thariq: 5-7, dan Al-Ghasiyyah: 17-20.

2. Tadabbara, yang berarti merenung yang terdapat pada surat Shaad: 29 dan Muhammad: 24

3. Tafakkara, yang berarti berpikir yang terdapat dalam 16 ayat di antaranya terdapat pada surah An-Nahl: 68-69 dan Al-Jatsiyah: 12-13

4. Faqiha, yang berarti mengerti atau faham yang terdapat dalam 16 ayat diantaranya pada surat Al-Isra; 44, Al-An'am: 97-98, dan At-Taubah:122

5. Tazakkara, yang berarti mengingat, memperoleh peringatan, mendapat pelajaran, memperhatikan dan mempelajari yang semuanya mengandung perbuatan berpikir yang terdapat dalam lebih dari 40 ayat di antaranya pada surat An-Nahl: 17, Az-Zumar: 9, dan Adz-Dzariyaat: 47-49

6. Fahima, yang berarti faham yang antara lain terdapat dalam surah Al-Anbiya: 78-79. ${ }^{19}$

Apa yang sudah diungkapkan menunjukkan adanya petunjuk yang jelas dari Allah SWT agar manusia senantiasa memaksimalkan kemampuan akalnya dalam segala aspek kehidupannya termasuk di dalamnya untuk menginterpretasikan berbagai fenomena keagamaan.

Kedudukan tinggi bagi akal dan perintah untuk memaksimalkan penggunaannya sebagaimana yang diajarkan Al-Qur'an bukan hanya merupakan

\footnotetext{
${ }^{19}$ Harun Nasution, Akal dan Wahyu Dalam Islam (Jakarta: UI Press;1986) h. 39-44
} 
Jurnal Pemikiran Konstruktif Bidang Filsafat dan Dakwah ISSN $1907-0993$

E ISSN $2442-8264$

Vol. 17 No. 1, Juni 2020

ajaran dalam teori, tetapi ajaran yang telah pernah diamalkan oleh para cendekiawan dan ulama Islam zaman klasik pada sekitar abad ke tujuh dan abad ke dua belas masehi yang merupakan masa keemasan bagi Islam. ${ }^{20}$

Pada masa itu akal manusia tidak hanya digunakan untuk menelaah ilmu-ilmu keagamaan semata tetapi juga menyangkut ilmu-ilmu seperti ilmu perbintangan, kedokteran, filsafat, politik, dan lain sebagainya. Karena pergumulan pengkajian yang intens antara pengetahuan-pengetahuan keagamaan dan umum pada masa itu, maka hampir-hampir tidak ada dikotomi antara ilmu agama dan ilmu umum bahkan dalam pengkajian antara keduanya seringkali terjadi over-lapping dalam pengertian bahwa ilmu-ilmu umum dan sebaliknya teori-teori umum digunakan untuk menganalisa berbagai fenomena keagamaan.

Dalam ranah pemikiran Islam tokoh yang cukup menonjol kajiannya tentang akal adalah pemikir Mesir kontemporer Muhammad Abduh. Akal menurutnya adalah suatu daya yang hanya dimiliki manusia dan karena itu dialah yang membedakan manusia dari makhluk lain. Akal adalah tonggak kehidupan manusia dan dasar kelanjutan wujudnya. Peningkatan daya akal merupakan salah satu dasar pembinaan budi pekerti mulai yang menjadi dasar dan sumber kehidupan dan kebahagiaan bangsa-bangsa. $^{21}$

Selanjutnya menurut Abduh, Islam adalah agama rasional, agama yang sejalan dengan akal, bahkan agama yang didasarkan atas akal. Pemikiran rasional adalah jalan untuk mendapatkan iman sejati. Iman tidaklah sempurna kalau tidak didasarkan pada akal. Iman harus berdasar pada keyakinan dan bukan pada pendapat dan akallah yang menjadi sumber keyakinan pada Tuhan, ilmu serta kemahakuasaan-Nya dan pada para Rasul. ${ }^{22}$

\footnotetext{
${ }^{20}$ Atho' Mudzhar dalam Budhy Munawar Rahman (Editor) Kontekstualisasi Doktrin Islam Dalam Sejarah (Jakarta: Yayasan Paramadina; 1995) h. 373

${ }^{21}$ Harun Nasution, Muhammad 'Abduh dan Teologi Rasional Mu'tazilah (Jakarta: UI Press, 1987) h. 44

${ }^{22}$ Harun Nasution, Muhammad 'Abduh dan Teologi Rasional Mu'tazilah, h. 45-46
} 
Jurnal Pemikiran Konstruktif Bidang Filsafat dan Dakwah ISSN $1907-0993$

E ISSN $2442-8264$

Vol. 17 No. 1, Juni 2020

Uraian-uraian di atas menunjukkan betapa akal mempunyai peranan yang besar dalam menjalankan keberagamaan suatu kaum dan itu sudah dibuktikan oleh umat Islam dalam sejarah. Karena akal mampu menginterpretasi berbagai fenomena keagamaan sesuai kadarnya dan pada realitasnya semua itu makin melengkapi keimanan, ketakwaan, dan keberagamaan seorang muslim.

\section{BEBERAPA INTERPRETASI RASIONAL ATAS FENOMENA KEAGAMAAN}

Sebagaimana diketahui, Islam berkembang dalam sejarah bukan hanya sebagai agama tetapi juga sebagai kebudayaan. Memang pada mulanya Islam hadir hanya sebagai sebuah agama di Mekah, tetapi kemudian tumbuh di Madinah menjadi negara, selanjutnya membesar di Damaskus menjadi kekuatan politik internasional yang luas daerah kekuasannya dan akhirnya berkembang di Baghdad menjadi kebudayaan bahkan peradaban yang tidak kecil pengaruhnya pada beberapa peradaban besar di dunia ini, misalnya pada peradaban Barat modern. Dalam perkembangan Islam itu, akal memainkan peranan penting bukan hanya dalam bidang kebudayaan saja, tetapi juga dalam interpretasi atas berbagai fenomena agama. Dalam membahas masalah-masalah keagamaan, ulama-ulama Islam tidak semata-mata berpegang pada wahyu, tetapi juga banyak bergantung pada pendapat akal. Peranan akal yang besar dalam menginteroretasi fenomenafenomena keagamaan antara lain tampak dalam bidang fiqih dan tafsir.

Ilmu fiqih pada dasarnya merupakan ilmu yang membahas pemahaman dan tafsiran ayat-ayat Al-Qur'an yang berkenaan dengan hukum. Akan tetapi perkembangan masalah hukum tak selamanya sejalan dengan jawaban ayat-ayat Al-Qur'an secara tekstual. Dalam konteks ini kemudian diperlukan ijtihad dalam hukum dan dalam ijtihad inilah pengaruh akal sangat menentukan sukses atau tidaknya ijtihad tersebut. Bahkan dalam realitasnya ada mazhab fiqih yang 
Jurnal Pemikiran Konstruktif Bidang Filsafat dan Dakwah

ISSN $1907-0993$

E ISSN $2442-8264$

Vol. 17 No. 1, Juni 2020

karena alasan-alasan tertentu cenderung rasional dalam membuat ketetapan hukum, contohnya mazhab Imam Abu Hanifah. ${ }^{23}$

Dalam praktek tafsir Al-Qur'an juga ada aliran yang dalam tafsirnya cenderung rasional dalam memaknai ayat-ayat Al-Qur'an. Aliran tafsir model ini disebut tafsir bil-ra'yi (penalaran). Yang dimaksud dengan penalaran dalam hal ini adalah ijtihad para mufassir dengan mengaitkan antara sumber-sumber tafsir yang ada (Al-Qur'an dan hadis) dengan kajian-kajian atau teori-teori ilmiah yang berlaku secara umum. ${ }^{24}$

Dengan kenyataan ini maka dapat dipastikan bahwa kemungkinan untuk menginterpretasi fenomena keagamaan dengan pendekatan-pendekatan rasional keilmuan sangat terbuka, karena semangat itu sesungguhnya inheren di dalam Al-Qur'an. Menurut Musthafa Shadiq Al-Rafi'i bahwa dalam Al-Qur'an seseorang mungkin dapat menemukan banyak petunjuk mengenai fakta-fakta keilmuan. Dan sains modern dapat membantu kita menafsirkan makna-makna berbagai ayat Al-Qur'an serta membantu menyingkap fakta-faktanya. ${ }^{25}$

Meskipun harus diakui bahwa Al-Qur'an bukanlah ensiklopedi sains yang komplit, tetapi juga tidak bisa dinafikan bahwa isyarat-isyarat ilmiah yang diungkapkan oleh Al-Qur'an bila dikomparasikan dengan realitas ilmiah maka itu adalah fenomena sains yang memukau dan bahkan dipandang sebagai simbol lompatan peradaban manusia. Hal itu antara lain berupa kemampuan manusia menembus belantara luar angkasa, proses penciptaan manusia dari titik yang paling awal, pertemuan dua arus air di laut Gibraltar, ungkapan Al-Qur'an tentang pertambangan, pertanian, peternakan, dan masih banyak lagi hal yang sudah cukup banyak membuktikan bahwa Al-Qura'an itu sarat dengan muatanmuatan rasional ilmiah yang tergolong luar biasa untuk ukuran sebuah kitab suci.

\footnotetext{
${ }^{23}$ Harun Nasution, Akal dan Wahyu.., h. 72-73

${ }^{24}$ Abuddin Nata, Metodologi Studi Islam (Jakarta: PT Raja Grafindo Persada, 2001) h.171

${ }^{25}$ Mahdi Ghulsyani, Filsafat Sains Menurut Al-Qur'an (Bandung: Mizan; 1998) h. 139
} 
Jurnal Pemikiran Konstruktif Bidang Filsafat dan Dakwah ISSN $1907-0993$

E ISSN $2442-8264$

Vol. 17 No. 1, Juni 2020

Semua uraian yang telah diungkapkan dalam tulisan ini sudah cukup membuktikan bahwa kemungkinan untuk memahami dan menginterpretasi fenomena keagamaan dengan teori-teori keilmuan bukanlah suatu hal yang tabu untuk dilakukan bahkan bila mungkin menjadi suatu keharusan untuk lebih memberi penekanan akan kebenaran fakta-faktanya. Ini semua akan berimplikasi pada kenyataan bahwa ungkapan-ungkapan Al-Qur'an adalah kebenaran yang tidak saja bersifat doktrinal, tetapi juga bersifat riil karena terbukti secara ilmiah. Lebih jauh lagi bahwa semua ini akan membuktikan klaim kebenaran Islam itu sendiri dan akhirnya akan makin meneguhkan keimanan orang Islam itu sendiri.

\section{E. PENUTUP}

Ditinjau dari segi cara penerimaan atas berbagai fenomena keagamaan maka ada dua cara atau pendekatan yang digunakan yaitu pendekatan ta'abbudi yang berarti menerima semua ketentuan agama dengan tunduk dan patuh kepada segala perintah dalam rangka penghambaan atau ibadah kepada Tuhan, cara ini banyak digunakan untuk menerima fenomena keagamaan yang berupa ibadah. Cara yang kedua adalah ta'aqquli yaitu penerimaan fenomena keagamaan secara rasional yang banyak menggunakan akal sebagai alat untuk melakukan pendekatan terhadap masalah-masalah yang berhubungan dengan mu'amalah.

Dalam rangka pendekatan keilmuan terhadap fenomena keagamaan maka akal memegang peranan yang sangat penting sebagaimana juga diisyaratkan dalam Al-Qur'an. Sebab penggunaan akal secara maksimal dan ideal dalam memahami fenomena keagamaan akan makin mempertebal keimanan atas klaim kebenaran Islam secara keseluruhan.

Penggunaan akal dalam pemahaman fenomena keagamaan antara lain tampak pada aspek fikir dengan adanya praktek ijtihad untuk menalar ketentuanketentuan hukum yang baru, yang status hukumnya tidak ditegaskan secara tekstual dalam Al-Qur'an dan hadis. Hal ini juga dilakukan dalam praktek penafsiran Al-Qur'an dengan adanya metode tafsir bil-ra'yi (penafsiran AlQur'an dengan bantuan penalaran akal). Hal ini dimungkinkan karena dalam Al- 
Jurnal Pemikiran Konstruktif Bidang Filsafat dan Dakwah ISSN $1907-0993$

E ISSN $2442-8264$

Vol. 17 No. 1, Juni 2020

Qur'an sendiri memungkinkan untuk mendapatkan informasi-informasi ilmiah sangat terbuka.

\section{DAFTAR PUSTAKA}

Arsyad, Aisyah, Memahami Rahasia Hukum Dalam Ruang Privat ( Huquq AlIbad), dalam Jurnal Sulesana Volume 11 Nomor 2 Tahun 2017

Bidran, Bidran Abul 'Ainain, Al-Ibadat Al-Islamiyyat (Iskandariyah: Mu'assasah Syabaab Al-Jamiah; 1973)

Candra, Diki, Akal dan Wahyu : Telaah Atas Pemikiran Kalam Harun Nasution dalam Jurnal Ad-Dirasah, Jurnal Hasil Pembelajaran Ilmu-ilmu Keislaman Volume 1 Nomor 1, 2018

Fatih, M., Paradigma Pemahaman dan Klasifikasi Sunnah dalam Perspektif Edukatif Mahmud Syaltut dan Implikasinya Terhadap Aktualisasi Mekanisme Ra'yu Era Kekinian, dalam Ta'dibia Jurnal Ilmiah Pendidikan Islam Volume 7 Nomor 1, 2017

Fitriyani, Hukum Islam dan Multikulturalisme di Indonesia, dalam Jurnal Tahkim Volume 12 Nomor 2 Tahun 2018

Ghulsyani, Mahdi, Filsafat Sains Menurut Al-Qur'an (Bandung: Mizan; 1998)

Haq, Hamka, Filsafat Ushul Fiqih (Ujung Pandang: Yayasan Al-Ahkam; 1999)

Hutasuhut, Efrianto, Akal dan Wahyu dalam Islam (Perbandingan Pemikiran Harun Nasution dan Muhammad Abduh) dalam Jurnal Al-Lubb Volume 2 Nomor 1 Tahun 2017

Jamaa, La, Konsep Ta'abbudi dan Ta'aqquli dan Implikasinya Terhadap Perkembangan Hukum Islam, dalam ASy-Syir'ah, Jurnal Ilmu Syari'ah dan Hukum, Volume 47 No.1 Tahun 2013

Kusnadi, Didi, Pemikiran Hukum Islam Klasik dan Modern: Karakteristik, Metode, Pengembangan, dan Keberlakuannya, dalam Jurnal AsySyar'iyah Volume 16 Nomor 1 Tahun 2014 


\section{FARABI}

Jurnal Pemikiran Konstruktif Bidang Filsafat dan Dakwah ISSN $1907-0993$

E ISSN $2442-8264$

Vol. 17 No. 1, Juni 2020

Masbukin, Hasan, Alimuddin, Akal dan Wahyu, Antara Perdebatan dan Pembelaan dalam Sejarah, dalam Jurnal Toleransi: Media Komunikasi Umat Beragama Volume 8 Nomor 2 Tahun 2016

Mudzhar, Atho', dalam Budhy Munawar Rahman (ed.), Kontekstualisasi Doktrin Islam Dalam Sejarah (Jakarta: Yayasan Paramadina; 1995)

Nasution, Harun, Akal dan Wahyu Dalam Islam (Jakarta: UI Press; 1986) Islam Ditinjau Dari Berbagai Aspeknya (Jakarta: UI Press; 1985) Muhammad Abduh dan Teologi Rasional Mu'tazilah (Jakarta: UI Press; 1987)

Nata, Abuddin, Metodologi Studi Islam (Jakarta: PT Raja Grafindo Persada; 2001)

Sabara, Polemik Akal dan Wahyu dalam Lanskap Pemikiran (Antara Rasionalisme vis a vis Fideisme) dalam Jurnal Ilmu Aqidah Volume 1 Nomor 1 Tahun 2015

Ash-Shiddieqy, TM Hasbi, Pengantar Imu Fiqih (Jakarta: Bulan Bintang; 1974)

As-Syathibi, Abu Ishak, Al-Muwafaqaat (Beirut: Dar Al-Ma'rifat; t.th.)

Zaelani, Abdul Qodir, Konsep Ta'aqquli dan Ta'abbudi dalam Konteks Hukum Keluarga Islam, dalam Jurnal ASAS Volume 6 Nomor 1, 2014

Zahrah, Abu, Ushul Fiqih (Kairo: Dar Al-Fikr Al-Arabi; t.th.) 